\title{
Penerapan Terapi Spiritual Emotional Freedom Technique (SEFT) Pada Penderita Tuberculosis dengan Masalah Keperawatan Ansietas di Puskesmas Sawahan Surabaya
}

\author{
Eppy Setyowati \\ Universitas Nahdlatul Ulama Surabaya, eppy@unusa.ac.id
}

\author{
Alfin Hidayatur Rahman \\ Universitas Nahdlatul Ulama Surabaya
}

\begin{abstract}
Abstrak
Penyakit tuberkulosis (TB) paru merupakan suatu penyakit infeksi yang disebabkan bakteri berbentuk batang (basil) yang dikenal dengan nama Mycobacterium tuberculosis. Basil tuberkel ini akan menyebabkan gangguan pernafasan. Selain itu proses penyakit dan pengobatan yang lama sering menyebabkan kecemasan pada penderita Tuberculosis. Tujuan penelitian ini adalah penerapan terapi SEFT pada pasien Tuberculosis untuk mengurangi ansietas di Puskesmas Sawahan Surabaya. Metode yang digunakan adalah deskriptif dengan pendekatan studi kasus melalui asuhan keperawatan dengan masalah keperawatan ansietas pada pasien Tuberculosis. Pengumpulan data yang dilakukan dengan menggunakan metode wawancara, observasi langsung, dan rekam medis. Hasil dari penerapan terapi SEFT yang dilakukan satu kali/hari selama 3 hari pada Tn.B didapatkan adanya penurunan ansietas yang teratasi secara bertahap setelah melakukan terapi SEFT. Penerapan terapi SEFT ini efektif untuk mengurangi ansietas yang dirasakan oleh pasien Tuberculosis. Oleh karena itu Perawat diharapkan dapat mengajarkan terapi SEFT sesuai standar operasional prosedur (SOP) sehingga pasien maupun keluarga dapat mempraktekan kembali dirumah.
\end{abstract}

Kata Kunci: Ansietas, Tuberculosis, SEFT

\begin{abstract}
Pulmonary tuberculosis (TB) is an infectious disease caused by rod-shaped bacteria (bacilli) known as Mycobacterium tuberculosis. This tubercle basil will cause respiratory problems. In addition, the disease process and long-term treatment often cause anxiety in people with Tuberculosis. The purpose of this study was the application of SEFT therapy in Tuberculosis patients to reduce anxiety in Sawahan Surabaya Health Center. The method used was descriptive with a case study approach through nursing care with anxiety nursing problems in Tuberculosis patients. Data collection is done using the method of interviews, direct observation, and medical records. The results of the application of SEFT therapy were carried out once / day for 3 days at Mr. B. There was a decrease in anxiety which was resolved gradually after SEFT therapy. The application of SEFT therapy is effective in reducing anxiety felt by Tuberculosis patients. Therefore nurses are expected to be able to teach SEFT therapy according to standard operating procedures (SOP) so that patients and families can practice it again at home.
\end{abstract}

Keywords: Anxiety, Tuberculosis, SEFT

\section{PENDAHULUAN}

Tuberkulosis (TB) merupakan suatu penyakit infeksi menular yang disebabkan bakteri Mycobacterium Tuberculosis, yang dapat menyerang berbagai organ, terutama paru-paru. Tuberkulosis bila tidak diobati atau pengobatannya tidak tuntas dapat menimbulkan komplikasi berbahaya hingga kematian (Kementrian Kesehatan Republik Indonesia, 2016). Penyakit ini dapat menular melalui udara dari orang yang terinfeksi ke orang lain, salah satunya 
melalui batuk produktif karena adanya peningkatan produksi sekret dan sekresi sputum yang purulen (Muttaqin, 2012). Sekret yang terkumpul pada saluran napas bila tidak dikeluarkan dapat menyebabkan obstruksi jalan napas yang menyebabkan bersihan jalan napas tidak efektif.

World Health Organization (WHO), TB menduduki posisi kedua sebagai penyakit infeksi yang menyebabkan kematian terbanyak pada penduduk dunia setelah Human Immunodeficiency Virus (HIV). Indonesia berada di posisi ke-3 setelah India dan China, yaitu sebanyak 360.565 kasus. Dalam perkiraan antara tahun 2000-2020 kematian karena TB meningkat sampai 35 juta orang. Setiap hari ditemukan 23.000 kasus TB dan menyebabkan hamper 5000 kematian. Secara Global perkiraan insiden TB pada tahun 2010 adalah 8,8-9,4 juta, pada tahun 2011 TB menempati posisi kedua sebagai penyebab utama kematian dengan beban global yaitu 8,7 juta kasus baru, 12 juta kasus baru dan lama, dan 1,4 juta kematian Hasil Survei Prevalensi TB Indonesia tahun 2017 memperlihatkan angka penemuan sebanyak 360.770 kasus. (Kemenkes RI, 2018; World Health Organization, 2017).

Hasil Riset Kesehatan 2013, prevalensi penduduk Indonesia yang didiagnosis TB paru oleh tenaga kesehatan tahun 2013 adalah $(0.4 \%)$, tidak berbeda dengan 2007. Lima provinsi dengan TB paru tertinggi adalah Jawa Barat (0.7\%), Papua (0.6\%), DKI Jakarta (0.6\%), Gorontalo (0.5\%), Banten (0.4\%) dan Papua Barat $(0.4 \%)$, Jawa timur $(0.2 \%)$ (Riskesdas, 2013). Data TB di Jawa Timur pada 2015, kabupaten/Kota terbanyak pasien TB yang diobati dari Surabaya (4.754), Jember (3.128), Sidoarjo (2.292), Kabupaten Malang (1932) dan Kabupaten Pasuruan (1809) (Dinkes Jawa Timur, 2016). Hasil studi pendahuluan di Puskesmas Sawahan menunjukkan jumlah penderita TB dalam tiga bulan terakhir terhitung dari Maret hingga Mei 2019 yaitu sejumlah 39 penderita dan 10 diantaranya memiliki masalah ansietas.

Bagi penderita Tuberculosis yang mengalami kecemasan dikarenakan kurangnya pengetahuan dan sering bertanya tentang penyakit Tuberculosis. Hal ini tentunya sangat berbahaya bagi penderita. Pada saat penderita batuk atau bersin, kuman TB paru dan BTA positif yang berbentuk droplet sangat kecil akan betertebangan di udara. Droplet yang sangat kecil ini kemudian mengering dengan cepat dan menjadi droplet yang mengandung kuman tuberkulosis. Kuman ini dapat bertahan di udara selama beberapa jam lamanya, sehingga cepat atau lambat droplet yang mengandung unsur kuman tuberculosis akan terhirup oleh orang lain. Apabila droplet ini telah 
terhirup dan bersarang di dalam paru-paru seseorang, maka kuman ini akan mulai membelah diri atau berkembang biak sehingga dapat menginfeksi dari satu penderita ke penderita yang lain. Penyakit tuberculosis paru bila tidak ditangani dengan benar akan menimbulkan komplikasi. Menurut Ardiansyah M (2012), komplikasi dini antara lain: pleuritis, efusi pleura empiema, laringitis dan TB usus. Selain itu, juga dapat menimbulkan komplikasi yang lebih lanjut seperti obstruksi jalan nafas, kor pulmonale dan amiloidosis.

Untuk mencegah komplikasi tersebut maka dibutuhkan peran dan fungsi perawat dalam melakukan asuhan keperawatan yang benar meliputi promotif, preventif, kuratif dan rehabilitative yang dilakukan secara komprehensif dengan menggunakan pendekatan proses keperawatan. Peran perawat dalam promotif dan preventif yakni memberikan pendidikan kesehatan tentang TB paru dan penularan TB paru terhadap keluarga maupun pasien itu sendiri. Dalam upaya penanggulangan penyakit $\mathrm{Tb}$ paru, peran serta keluarga dalam kegiatan pencegahan merupakan faktor yang sangat penting. Peran serta keluarga dalam penanggulangan TB paru harus diimbangi dengan pengetahuan yang baik. Peran perawat kuratif yakni memberikan pengobatan TB paru menggunakan obat anti tuberculosis (OAT) harus adekuat dan minimal 6 bulan, hal ini bertujuan untuk mencegah terjadinya resitensi basil TB terhadap obat. Pengobatan tuberkulosis paru menggunakan obat anti tuberkulosiis (OAT) dengan metode directly observed treatment shortcouse (DOTS). Selain dalam hal pengobatan farmakologi juga dapat diberikan pengobatan nonfarmakologi dengan memberikan terapi SEFT (Spiritual Emotional Freedom Technique) pada penderita TB paru. Pengobatan non farmakologi melalui terapi SEFT telah dibuktikan oleh peneliti sebelumnya yaitu Kusnanto, dkk 2016 mampu meningkatkan kualitas hidup pada penderita tuberculosis paru dengan hasil $89 \%$ penderita mampu mengurangi kecemasan, $76 \%$ penderita mampu menguasai kemampuan diri terhadap penyakitnya dan $78 \%$ mampu bersosialisasi pada lingkungan kerja maupun lingkungan sosial lainnya.

\section{METODE}

Jenis penelitian kualitatif dengan pendekatan studi kasus. Sampel penelitian 32 responden dengan masalah keperawatan ansietas yang diambil melalui snowball sampling. Data dikumpulkan melalui wawancara langsung terhadap klien dan pengamatan langsung terhadap 
klien. Intervensi yang akan dilakukan ialah penerapan terapi spiritual emotional freedom tehnique (SEFT) pada responden dengan masalah keperawatan ansietas terhadap penyakit dan proses pengobatan lama yang telah ditunjuk sebagai sampel studi kasus di wilayah kerja Puskesmas Sawahan Surabaya.

\section{HASIL PENELITIAN}

Penderita tuberkulosis paru dan sudah berobat ke puskesmas sawahan 6 bulan sampai dengan 1 tahun. Tiga puluh dua (32) responden sampel penelitian yang dilakukan pada wilayah kerja Puskes Sawahan Surabaya didapatkan data bahwa pemeriksaan terhadap Tensi didapatkan rata $110 / 90$ mmhg sampai dengan $130 / 80$ mm hg. Tensi 110/90 mmhg didapatkan sebanyak 43,5 \%, tensi $120 / 90$ sebanyak $35,2 \%$ dan tensi 130/80 mmhg 32,3\%. Hal tersebut menunjukan bahwa rata-rata tensi pada responden masih dalam batas normal. Keluhan yang dirasakan adalah kecemasan terkait dengan pengobatan yang lama dan penyakitnya tidak berangsur sembuh.

\section{PEMBAHASAN}

Ruang lingkup pembahasan ini meliputi pegkajian, diagnosa keperawatan, rencana keperawatan, implementasi dan evaluasi. a. Pengkajian

Pengkajian merupakan tahap awal dan landasan dalam proses keperawatan untuk itu diperlukan kecermatan dan ketelitian dalam menangani masalahmasalah klien sehingga dapat menentukan tindakan keperawatan yang tepat. Pada tanggal tanggal 18 Juni 2019 sampai dengan 28 Juli 2019, data sebagian besar diambil dari rekam medis di Puskesmas Sawahan selanjutnya dilakukan kunjungan rumah untuk melakukan observasi kondisi responden. Pada tahap pengkajian ini juga dilakukan melalui rekan medis ditemukan data bahwa hasil pemeriksaan sputum BTA adalah positip.

Selanjutnya dari hasil pengkajian keluhan utama responden mengalami keluhan utama yaitu ansietas terhadap penyakitnya dan proses pengobatan yang lama. Terjadinya rasa ansietas karena responden tidak mengerti atau kurang pengetahuan dengan penyakit Tuberculosis. Tuberculosis ini merupakan suatu penyakit yang butuh penangan dengan tepat.

$$
\text { Menurut Kemenkes }
$$

Tuberkulosis adalah penyakit menular yang disebabkan oleh kuman Myobacterium tuberculosis. Penyebaran kuman tuberculosis ini terjadi di udara melalui dahak yang berupa droplet. Bagi penderita tuberculosis paru yang memiliki banyak sekali kuman, dapat terlihat 
langsung dengan mikroskop pada pemeriksaan dahaknya. Hal ini tentunya sangat menular dan berbahaya bagi lingkungan penderita. Pada saat penderita batuk atau bersin, kuman TB paru dan BTA positif yang berbentuk droplet sangat kecil akan betertebangan di udara. Droplet yang sangat kecil ini kemudian mengering dengan cepat dan menjadi droplet yang mengandung kuman tuberkulosis. Kuman ini dapat bertahan di udara selama beberapa jam lamanya, sehingga cepat atau lambat droplet yang mengandung unsure kuman tuberculosis akan terhirup oleh orang lain. Apabila droplet ini telah terhirup dan bersarang di dalam paru-paru seseorang, maka kuman ini akan mulai membelah diri atau berkembang biak sehingga dapat menginfeksi dari satu penderita ke penderita yang lain. Menurut Ardiansyah M (2012), komplikasi dini antara lain: pleuritis, efusi pleura empiema, laringitis dan TB usus. Selain itu, juga dapat menimbulkan komplikasi yang lebih lanjut seperti obstruksi jalan nafas, kor pulmonale dan amiloidosis.

b. Diagnosa Keperawatan

Prioritas diagnosa pada responden dengan masalah keperawatan ansietas yang berhubungan dengan stressor, karena sesuai dengan data yang di dapat dari responden menyatakan keluhan utamanya adalah cemas pada penyakitnya dan pengobatan yang lama. Hal ini sesuai juga dengan diagnosa keperawatan dan batasan karakteristik ansietas, yaitu adanya ekspresi wajah cemas sering bertanyatanya tentang proses pengobatan. Menurut Namora Lumongga Lubis (2009), kecemasan adalah rasa takut atau khawatir pada situasi tertentu yang sangat mengancam yang dapat menyebabkan kegelisahan karena adanya ketidakpastian dimasa mendatang serta ketakutan bahwa sesuatu yang buruk akan terjadi.

Dari data diatas penulis memfokuskan pembahasan pada prioritas masalah ansietas yang berhubungan dengan stressor. Ansietas yang dirasakan pasien karena kurangnya pengetahuan pasien tentang penyakit Tuberculosis sehingga yang muncul adalah diagnosa keperawatan ansietas. Untuk diagnosa keperawatan jalan nafas tidak efektif tidak diprioritaskan dalam asuhan keperawatan ini dikarenakan responden tidak menunjukan sesak. Meskipun pada jalan nafasnya ditemukan suara ronchi akan tetapi pasien sudah meminum OAT sehingga menurut penulis jalan nafas tidak efektif tidak diprioritaskan.

c. Perencanaan Keperawatan

Intervensi yang digunakan dalam perencanaan keperawatan untuk mengatasi ansietas pada responden adalah dengan pengurangan kecemasan dan memberikan 
edukasi terhadap proses pengobatan yang lama dan prosedural.

Menurut Namora Lumongga Lubis (2009), pengurangan kecemasan adalah meminimalkan ketakutan, prasangka, kegelisahan yang berhubungan dengan sumber bahaya yang tidak dapat diidentifikasi. Pengurangan kecemasan yaitu dengan cara gunakan pendekatan yang menenangkan, mengajarkan tehnik penanganan cemas, meyakinkan klien agar tidak cemas padaa kondisinya, dan memotivasi klien (Nanda, 2017). Pengurangan kecemasan direncanakan pada responden dan keluarganya sehingga diharapkan kecemasan berkurang.

d. Implementasi Keperawatan

Penanganan kecemasan pada responden dilakukan selama 1x/hari selama 3 hari dengan masalah keperawatan ansietas. Hal ini sesuai dengan penelitian Kusnanto (2016) terapi SEFT dapat mengurangi kecemasan pada pasien Tuberculosis. Terapi SEFT yang sudah dilakukan akan menimbulkan keikhlasan bagi pasien, sehingga pasien akan menerima dengan positif penyakit yang sedang dialami melalui ketabahan hati, harapan sembuh, serta mampu mengambil hikmah. Hal tersebut akan mengurangi kecemasan pada pasien Tuberkulosis, dengan indikator perbaikan pada aspek fisik, sosial, dan psikologis. Bukti-bukti ilmiah mengatakan bahwa pada penyakit yang umum sekalipun, kondisi, pikiran, emosi, sikap, kesadaran, dan doa-doa yang dipanjatkan oleh atau untuk pasien sangat berpengaruh bagi kesembuhannya.

Hal tersebut akan berdampak positif pada pengurang kecemasan pasien. SEFT dapat menurunkan kecemasan dikarenakan pada terapi SEFT terdapat kerja energi psikologi yaiut sekumpulan tehnik yang memanfaatkan sistem energi tubuh untuk memperbaiki kondisi pikiran atau emosi sesorang. Terapi SEFT pada Tn.B dapat dilakukan selama maksimal 3 hari dikarenakan Tn.B kooperatif saat dilakukan terapi SEFT.

e. Evaluasi

Pada responden setelah dilakukan terapi SEFT selama 3 hari dengan frekuensi 1 kali/hari menunjukan masalah ansietas berkurang terbukti dengan penderita mampu bersosillisasi dengan lingkungan sekitar, penderita $\mathrm{Tb}$ paru bersedia menggunakan masker walaupun ditempat umum, penderita mau minum susu yang sudah disediakan oleh puskesmas secara gratis.

Menurut Dr. William A. Tiller (2017) di dalam tubuh masing-masing manusia terdapat 7 level realitas sistem energi, yaitu yang pertama adalah level fisik disebut juga coarse particulate substance. Level kedua adalah prephysical body, disebut juga fine information wave. Lapis ketiga adalah 
emotional domain, keempat adalah mind domain, kelima lower spirit self, dan yang keenam (yang terdalam) yaitu high spirit seft. Dan satu level diantara level 2 dan 3 yang disebut astral level. Menariknya ketujuh level ini dikendalikan oleh "pikiran" pikiran kitalah yang bertanggung jawab menghubungkan antara level yang satu dengan level yang lainnya, serta mengkoordinasikan level-level substansi tersebut.

Masalah ansietas dapat teratasi pada responden dan tahap demi tahap intervensi dan implementasi dilakukan secara maksimal. Edukasi terhadap proses pengobatan yang lama juga bisa diterima dan responden juga menjalankan proses pengobatan tersebut..

\section{SIMPULAN}

Penerapan Terapi Spiritual Emotional Freedom Technique (SEFT) dapat mengurangi ansietas pada pasien Tn.B dengan Tuberculosis di Puskesmas Sawahan Surabaya

\section{REFERENSI}

Anggraini. 2016. Efektivitas Terapi Spiritual Emotional Freedom Technique (SEFT) Terhadap Kecemasan.

Ardiansyah, M. 2012. Medikal Bedah. Yokjakarta: DIVA Press.

Aspiani , R.Y. (2014). Buku Ajar Asuhan Keperawatan Gerontik. Jakarta: Trans Info Media.
Depkes RI. (2010). Pedoman Nasional Penannggulangan Tuberkulosis. Jakarta: Tidak Diterbitkan.

Donna L, Wong. (2008). Buku Ajar Keperawatan Pedriatik. Cetakan Pertama. Jakarta: EGC.

Elfiky, Ibrahim. Terapi Berfikir Positif. Bandung: Gita Print, 2009.

Kemenkes RI. Profil Kesehatan Indonesia tahun 2014. Jakarta: Kemenkes RI;2015.

Kusnanto., Retnayu, Inas Alifi. Spiritual Emotional Freedom Technique (SEFT) terhadap Kualitas Hidup Penderita Tuberculosis Paru. JKPVolume 4 Nomor 3 Desember 2016

Muhith, A., \& Siyoto, S. (2016). Pendidikan Keperawatan Gerontik. Yogjakarta: ANDI.

Naga, S.Sholeh. 2012. Buku Panduan Lengkap Ilmu Penyakit Dalam. Jogjakarta: CV. Sagung Seto.

Price, Sylvia Anderson dan Lorraine McCarty Wilson. 2006. Patofisiologi Konsep Klinis Proses-Proses Penyakit. Dialih bahasakan oleh Brahm U Pendit, dkk. Jakarta: EGC.

Sumantri, Arif. 2010. Kesehatan Lingkungan \& Perspektif Islam. Jakarta: Kencana.

Sunaryo, Wijayanti, Rahayu. (2016). Asuhan Keperawatan Gerontik. Yogjakarta: CV ANDI OFFSET.

Tamher, S. \& Noorkasiani. (2009). Kesehatan Usia Lanjut dengan Pendekatan Asuhan Keperawatan. Jakarta: Salemba Medika.

Widagdo. (2011). Masalah dan Tatalaksana Penyakit Infeksi. Jakarta: Sagung Seto. 